\title{
47. EVIDENCE FOR SULFATE-REDUCING AND METHANE-PRODUCING MICROORGANISMS IN SEDIMENTS FROM SITES 618, 619, AND 6221
}

\author{
Jean K. Whelan, Ronald Oremland, Martha Tarafa, Richard Smith, Robert Howarth, and Cindy Lee ${ }^{2}$
}

\begin{abstract}
Radiolabeled products were formed from labeled substrates during anaerobic incubation of sediments from Sites 618,619 , and 622 . One set of experiments formed ${ }^{14} \mathrm{CO}_{2},{ }^{14} \mathrm{CH}_{4}$, and ${ }^{35} \mathrm{SH}_{2}$ from $2-{ }^{14} \mathrm{C}$-acetate and ${ }^{35} \mathrm{~S}$-sulfate; a second set formed ${ }^{14} \mathrm{CH}_{4}$ from ${ }^{14} \mathrm{C}$-methylamine or ${ }^{14} \mathrm{C}$-trimethylamine. Levels of ${ }^{14} \mathrm{CO}_{2}$ and ${ }^{35} \mathrm{~S}^{2-}$ formed were two to three orders of magnitude greater than ${ }^{14} \mathrm{CH}_{4}$. Production of ${ }^{14} \mathrm{CH}_{4}$ by Deep Sea Drilling Project (DSDP) sediments was four to five orders of magnitude less than that formed by anoxic San Francisco Bay sediment. However, incubation of Site 622 sediment slurries under $\mathrm{H}_{2}$ demonstrated production of small quantities of $\mathrm{CH}_{4}$. These results indicate that DSDP sediments recovered from 4 to $167 \mathrm{~m}$ sub-bottom (age $85,000-110,000 \mathrm{yr}$.) harbor potential microbial activity which includes sulfate reducers and methanogens. Analysis of pore waters from these DSDP sites indicates that bacterial substrates (acetate, methylated amines) were present.
\end{abstract}

\section{INTRODUCTION}

The purpose of this project was to carry out shipboard experiments to test for anaerobic microbiological activity in cores recovered from sub-bottom depths of up to $200 \mathrm{~m}$ by the Deep Sea Drilling Project. Such activity is generally thought to be confined to surface sediments of sub-bottom depths of less than about $10 \mathrm{~m}$. To date, there have been a number of reports of successful experiments to detect or culture anaerobic bacteria from sediments to sub-bottom depths of at least $200 \mathrm{~m}$ (Davis, 1967 and references cited therein; Oremland et al., 1982; Balyaev and Ivanov, 1983). However, the ability to culture microorganisms from a sediment sample does not mean that those organisms are active at depth. The presence of microbial activity in rapidly depositing organicrich deep ocean cores is strongly suggested by geochemical indicators. These include: (1) a generally abrupt biogenic methane gradient occurring at sub-bottom depths of about $50-100 \mathrm{~m},(2)$ pore-water characteristics in and above the methane zone which follow the pattern expected if each deeper (older) horizon of microorganisms were taking advantage of the successively more reducing environment created by its predecessors, and (3) isotopic evidence (Rice and Claypool, 1981; Claypool and Kaplan, 1974; Whelan, 1979; Whelan and Sato, 1980, among others).

It is difficult to obtain definitive results from microbiologically oriented experiments because, if no activity is found, the cause could be either absence or mortality of organisms in sediments recovered from depth. On the other hand, if activity is found, the potential for contamination with surficial sediment must be carefully con-

\footnotetext{
${ }^{1}$ Bouma, A. H., Coleman, J. M., Meyer, A. W., et al., Init. Repts. DSDP, Washington (U.S. Govt. Printing Office).

2 Addresses: (Whelan, Tarafa, Lee) Chemistry Department, Woods Hole Oceanographic Institution, Woods Hole, MA 02543; (Oremland) Division of Water Resources, U. S. Geological Survey, Menlo Park, CA 94025; (Smith) Division of Water Resources, U.S. Geological Survey, Lakewood, CO 80215; (Howarth) Marine Biological Laboratories, Woods Hole Oceanographic Institution, Woods Hole, MA 02543.
}

sidered. Recognizing these difficulties, we felt it was important to test further for anaerobic bacterial activity for several reasons. First, questions about the safety of drilling a specific site and depth often hinge on the source and migration mechanisms of $\mathrm{C}_{1}-\mathrm{C}_{5}$ gases in areas of rapidly depositing sediments so that mechanisms of gas formation need to be better understood. Second, if it could be shown that anaerobic organisms are active at depth, they might be responsible for some of the gradual downhole changes observed in sediment organic matter which have previously been attributed to low temperature chemical diagenesis or depositional changes. An ancillary goal of this work was to develop simple methodology that could be used in testing for the presence of microorganisms on future Ocean Drilling Project cruises. We hope that the results described below, which should be viewed as preliminary, will encourage more sophisticated microbiological experiments on future Ocean Drilling Program cruises.

\section{EXPERIMENTAL METHODS}

\section{Sampling Procedure}

All DSDP sediments used in this study were taken with the downhole hydraulic piston corer (HPC) during Leg 96, resulting in generally high quality, relatively undisturbed cores. Core recovery of stiff gray mud, which had the consistency of thick putty, was generally 80 $90 \%$. Fine-scale bedding and other sediment features were usually clearly defined in sections adjacent to those used in this work. Thus, intervals of surface caving and contamination could have been identified and were avoided when sampling. Samples were taken from $60 \mathrm{~cm}$ whole-round lengths of core obtained by cutting the core plus liner with a pipe cutter at the two ends and capping both ends. Samples were refrigerated within $30 \mathrm{~min}$. of bringing the core on deck.

\section{Shipboard Microbiological Experiments (Sites 618 and 619):} Radiolabeled Substrates

Subsamples were taken from the whole-round sections for the microbiological work, usually within $24 \mathrm{hr}$. after the core was first brought on deck. Caps on the whole-round sample were removed and the ends of the core were sliced off with a sterile spatula. The core was then subsampled parallel to the core liner by pushing a $20-\mathrm{ml}$ plastic syringe with the hub end cut off into the sediment. A 10- to 20-ml aliquot of sediment was withdrawn and dispensed into a $50-\mathrm{ml}$ sterile round-bot- 
tom flask by pushing the sediment out of the syringe with the plunger and forcing it against the bottom of the flask. All glassware was sterilized by autoclaving, and aseptic procedures (e.g., flame sterilization) were used for all sample manipulations. Transfer of sediment to flasks was done under a flow of high-purity nitrogen passed through an indicating oxygen trap $(\mathrm{J}+\mathrm{W}$ Scientific). The sample flask was sealed by wiring a rubber stopper onto the top and further flushed with nitrogen through the stopper via sterile syringe needles for $10 \mathrm{~min}$.

A series of three to six identical flasks were prepared in this way from each whole-round sample with three sediment subsamples being taken from each core end. Each series of flasks received either ${ }^{14} \mathrm{C}$ methylamine $(0.5 \mathrm{ml}, 5 \mu \mathrm{Ci}$, specific activity $46.0 \mathrm{mCi} / \mathrm{mmol}$, New England Nuclear, Boston, MA) or $2-{ }^{14} \mathrm{C}$-acetate $(0.5 \mathrm{ml}, 5 \mu \mathrm{Ci}$, specific activity $55 \mathrm{mCi} / \mathrm{mmol}$, New England Nuclear, Boston, MA), together with ${ }^{35} \mathrm{~S}$-sulfate $\left(0.5 \mathrm{ml}, 5 \mu \mathrm{Ci}\right.$, carrier-free ${ }^{35} \mathrm{~S}$-sulfuric acid). The flasks were then incubated at room temperature $\left(\sim 15^{\circ} \mathrm{C}\right)$ for varying time periods. During the incubation, individual flasks were "sacrificed" by injection of $2 \mathrm{ml}$ of $10 \mathrm{~N}$ sodium hydroxide followed by freezer storage $\left(-20^{\circ} \mathrm{C}\right)$ in order to terminate bacterial activity. For each time series, one flask was sacrificed at zero time (usually within an hour after preparation); the others were typically sacrificed at intervals of 3,6, and 9 days. After sampling, the remaining core was recapped and refrigerated for the shore-based geochemical studies, including acetate and methylamine pore-water measurements (see below).

The incubation flasks were kept frozen until they were analyzed for radiolabeled metabolic end products $\left({ }^{14} \mathrm{CO}_{2},{ }^{14} \mathrm{CH}_{4}\right.$, and $\left.{ }^{35} \mathrm{SH}_{2}\right)$ about 6 weeks later.

\section{${ }^{14} \mathrm{CH}_{4}$ Analysis}

In order to detect the small quantities of ${ }^{14} \mathrm{CH}_{4}$ formed from ${ }^{14} \mathrm{C}$ labeled methanogenic substrates (acetate and methylamine) added to these DSDP sediments, it was necessary to devise a method that was more sensitive than the gas chromatographic/gas proportional counting (GC/GPC) techniques commonly used in microbial ecology. A procedure was developed ( $R$. Oremland) whereby the entire phase contents of experimental flasks were swept through a series of cold traps (to retain volatile ${ }^{14} \mathrm{C}$-precursors and ${ }^{14} \mathrm{CO}_{2}$ ), passed through a CuO oxidation furnace, and the resulting ${ }^{14} \mathrm{CO}_{2}$ trapped and counted by liquid scintillation spectrometry. Because the sample's entire gas phase $\left(\sim 40 \mathrm{~cm}^{3}\right)$ was used rather than only the small portion employed in GC/GPCs (e.g. $\sim 250 \mu l$ ), and since liquid scintillation is more sensitive than gas proportional counting, this method was $2-3$ orders of magnitude more sensitive than GC/GPC.

Helium carrier gas (flow $\sim 20 \mathrm{~cm}^{3} / \mathrm{min}$ ) was swept through the defrosted sample for about $10 \mathrm{~min}$. The emerging helium was vented into stainless steel tubing $(0.318 \mathrm{~cm}$ ID) and passed through three sequential Dewars-flask cold traps ( $\# 1=$ dry ice/propanol; \#2 and \#3 = liquid $\left.\mathrm{N}_{2}\right)$. The traps consisted of a continuous length $(\sim 6.5 \mathrm{~m})$ of coiled ( $25 \times 7 \mathrm{~cm} ; 6$ coils per trap) stainless steel tubing $(0.318 \mathrm{~cm} \mathrm{ID)}$ immersed halfway into the cold fluids. This procedure allowed ${ }^{14} \mathrm{CH}_{4}$ to pass through the traps while water vapor, ${ }^{14} \mathrm{CO}_{2}$, and volatile ${ }^{14} \mathrm{C}$ precursors were retained (efficiency $=100 \%$ ). After emerging from the traps, the ${ }^{14} \mathrm{CH}_{4}$-containing helium stream was passed through a $\mathrm{CuO}$ oxidation tube $(20 \times 1 \mathrm{~cm})$ held at $800-850^{\circ} \mathrm{C}$ (combustion efficiency $\geq 99 \%$ ). The resulting ${ }^{14} \mathrm{CO}_{2}$ in helium was bubbled through a mix of ethanolamine $(3 \mathrm{ml})$ and methanol $(9 \mathrm{ml})$ held in a scintillation vial. After trapping, toluene-based scintillation cocktail (8 ml; \#3a20; Res. Prod. Int'l.; Mount Prospect, Illinois) was added and the sample counted. Background counts ( $\sim 30 \mathrm{dpm}$ [disintegrations per minute]) were subtracted from sample counts, and counting efficiencies were calculated using ${ }^{14} \mathrm{C}$-toluene internal standards.

Cold traps were replaced after every 10 samples to prevent both line clogging (due to ice formation) and any "spill over" of ${ }^{14} \mathrm{C}$-labeled precursors. Traps were regenerated by back-flushing with air at $120^{\circ} \mathrm{C}$ for $>2 \mathrm{hr}$. This cold trapping system was used for all the sediment incubations conducted on the DSDP samples.

The procedure described above was modified to improve efficiency of operation and used for the shore-based confirmation experiments conducted with Site 622 and San Francisco Bay sediments. A short section $(\sim 90 \mathrm{~cm})$ of $0.635 \mathrm{~cm}$ ID stainless steel tubing was attached to the first trap (dry ice/propanol). This prevented clogging due to ice formation. A helium back-flush line was connected to the system via two four-port Valco valves (Fig. 1). Back-flushing the line removed
${ }^{14} \mathrm{C}$-precursors retained in the traps and eliminated the need to change traps after every 10 samples. The helium flow was reversed after each sample was trapped. Cold traps were then removed and replaced with Dewar flasks containing hot $\left(90-100^{\circ} \mathrm{C}\right)$ water. A heat gun was used to heat the non-immersed sections of the trapping line. Back-flushed helium was bubbled through a water trap (to retain ${ }^{14} \mathrm{C}$-labeled precursors) which vented to the hood. The back-flush procedure was followed for $\sim 10 \mathrm{~min}$. after each sample. This increased time per sample run to about $25 \mathrm{~min}$., but enhanced the overall efficiency of the procedure.

System line blanks were run prior to and after each incubation sample series (e.g., every three to four samples). This was done to ensure against any possible "spill over" of ${ }^{14} \mathrm{C}$-labeled substances from previous runs. In most cases, line blanks were equivalent to background counts. However, in highly active samples (San Francisco Bay mud), high line blanks were detected (Figs. 4 and 5), which were about $1 \%$ of the disintegrations per minute collected in the samples. These line blanks were probably caused by retention of small quantities of ${ }^{14} \mathrm{CH}_{4}$ in the trapping line.

Chemical blanks for the above procedure consisted of samples of sediment of the same general consistency and type, and from the same general area (Site 622) which had been refrigerated for 14 months. Samples were prepared as described above. One was treated with ${ }^{14} \mathrm{C}$ trimethylamine followed immediately by $2 \mathrm{ml}$ of $10 \mathrm{~N} \mathrm{NaOH}$. A second was treated with ${ }^{14} \mathrm{C}$-acetate followed by $2 \mathrm{ml}$ of $10 \mathrm{~N} \mathrm{NaOH}$. Both were frozen for a week and then analyzed for ${ }^{14} \mathrm{C}$-methane. Only background levels of ${ }^{14} \mathrm{C}$-methane were detected (Figs. 4 and 5).

\section{${ }^{14} \mathrm{CO}_{2}$ and ${ }^{35} \mathrm{SH}_{2}$ Analyses}

The procedure for measuring ${ }^{14} \mathrm{C}$ in carbon dioxide and ${ }^{35} \mathrm{~S}$ in the hydrogen sulfide is described in Smith and Klug (1981a,b). Samples were acidified and flushed with a helium stream in order to pass carbon dioxide and hydrogen sulfide through a series of three traps each containing $1 \mathrm{~N} \mathrm{NaOH}$. Trap 1 and combined traps 2 and 3 were subsampled and the aliquots counted to give a combined ${ }^{14} \mathrm{CO}_{2}$ and ${ }^{35} \mathrm{SH}_{2}$ count. A second subsample of each trap was then added to an equal volume of saturated $\mathrm{BaCl}$ solution to remove ${ }^{14} \mathrm{CO}_{2}$ as barium carbonate precipitate. The barium carbonate was centrifuged into a pellet and a subsample of the supernate liquid was counted using liquid scintillation spectrometry. This procedure effectively removed all of the ${ }^{14} \mathrm{CO}_{2}$, as determined with ${ }^{14} \mathrm{C}$-bicarbonate standards, and gave the ${ }^{35} \mathrm{~S}$-hydrogen sulfide counts. Carbon dioxide $\left({ }^{14} \mathrm{C}\right)$ values were then calculated by difference.

\section{Shore-Based Methanogenesis Experiments: (Site 622 and San}

\section{Francisco Bay)—Radiolabeled Substrates}

In order to reproduce the ${ }^{14} \mathrm{CH}_{4}$ experiments conducted at sea, an incubation was run in the laboratory. One whole-round section from Site 622 (Sample 622-4-1, 130-150 cm), very similar in appearance and consistency to sediments from Sites 618 and 619, was used. The sediment was stored at $12^{\circ} \mathrm{C}$ for 14 months before being sampled and sealed in stoppered flasks under nitrogen as described above. Triplicate samples were analyzed for each time point shown in Figures 4 and 5 (error bars represent $1 \sigma$ standard deviation). Each of nine flasks received $5 \mu \mathrm{Ci}$ of ${ }^{14} \mathrm{C}$-trimethylamine in $0.2 \mathrm{ml}$ solution (specific activity $=3.8 \mathrm{mCi} / \mathrm{mmol}$; Pathfinder Lab. Inc., St. Louis, $\mathrm{MO}$ ) and another nine with $5 \mu \mathrm{Ci}$ of $2{ }^{14} \mathrm{C}$-acetate in $1 \mathrm{ml}$ of solution (specific activity $=55 \mathrm{mCi} / \mathrm{mmol}$; New England Nuclear, Boston, MA). Six samples (three for each substrate) were then immediately frozen. The remaining flasks were allowed to stand at room temperature until the time when the incubations were stopped by freezing. Radiolabeled methane was measured as described previously.

To determine how the experimental methodology responded to sediments containing relatively high levels of methanogenic activity, incubations similar to those described above were also carried out on freshly collected San Francisco Bay mud. The results are shown in Figures 4 and 5 with the "blank" values representing residual radioactivity swept out of the methane combustion line between samples. If a sample suspected of having low activity was to be measured, the high blank was reduced to lower values by back-flushing and heating the gas line, then allowing the system to back-flush overnight. In this way, the blank prior to analysis of the 14-day Site 622 acetate determination (Fig. 4) was obtained after analyses of all of the San Francisco Bay samples (with much higher activity levels) had been completed. 


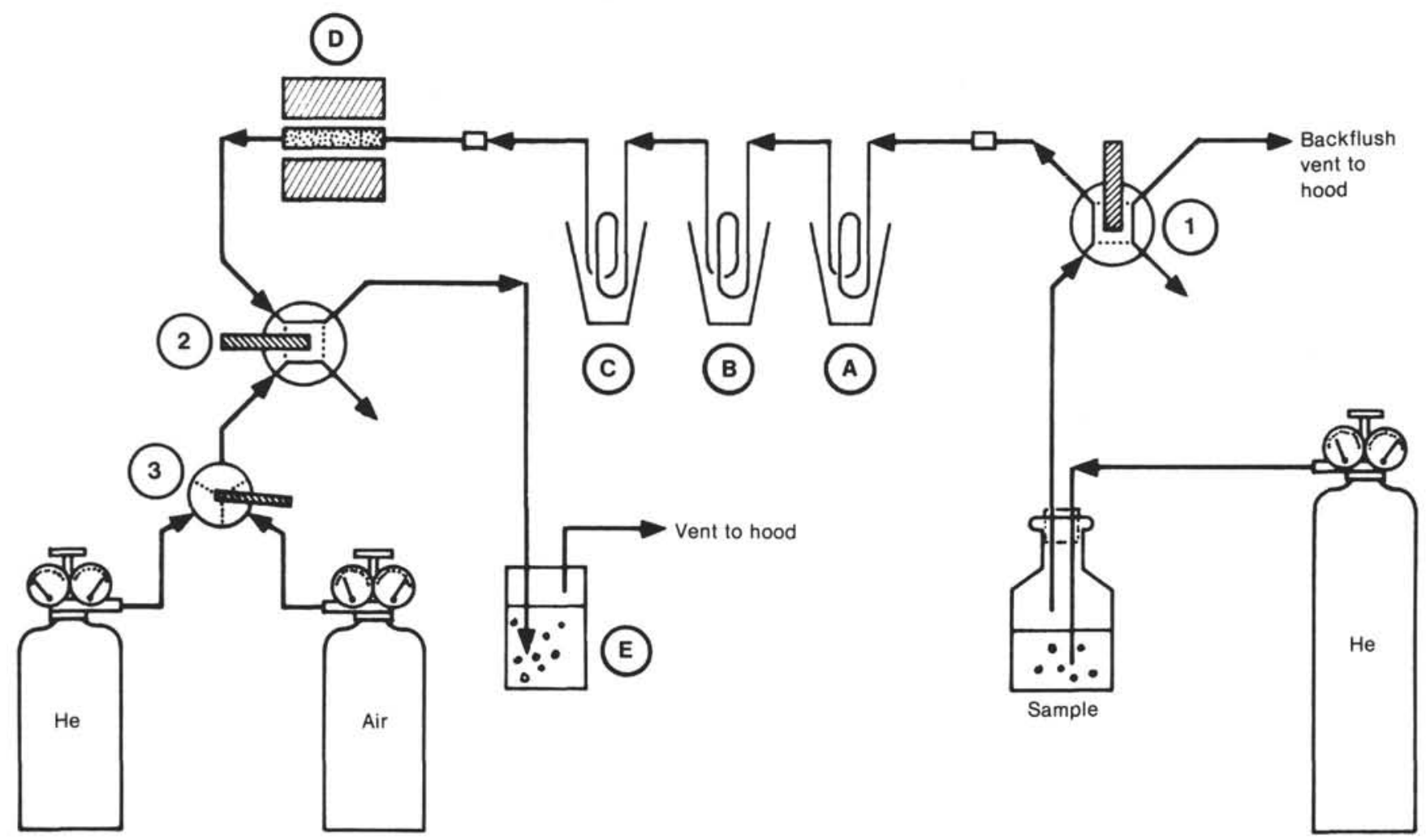

Figure 1. Modified ${ }^{14} \mathrm{CH}_{4}$ trapping/extraction system used in the laboratory experiments. Helium-vented sample flow passes through a four-way valve (1), a dry ice/propanol trap (A), and two liquid $\mathrm{N}_{2}$ traps (B and C). Sample is oxidized in CuO furnace (D), channeled through another four-way valve (2) and bubbled through ethanolamine/methanol trapping solution (E). In the back-flush mode, valves 1 and 2 are switched and flow is directed to hood. Valve 3 allows choice of either $\mathrm{He}$ (for line back-flushing) or air (for CuO trap regeneration).

The Site 622 zero-time experiments showed no ${ }^{14} \mathrm{C}$-methane production. Therefore, two of these samples were used to rule out chemical production of ${ }^{14} \mathrm{CH}_{4}$ under the experimental conditions. One flask for each substrate was treated with $2 \mathrm{ml}$ of $10 \mathrm{~N} \mathrm{NaOH}$ solution and then frozen. The samples were thawed and analyzed for ${ }^{14} \mathrm{C}$ about $24 \mathrm{hr}$. later. Only background counts $(<30 \mathrm{dpm})$ were detected for either the ${ }^{14} \mathrm{C}$-trimethylamine or $2-{ }^{14} \mathrm{C}$-acetate substrates (Figs. 4 and 5 ). Thus, ${ }^{14} \mathrm{C}$-methane produced in shipboard experiments cannot be the result of $\mathrm{NaOH}$ reacting chemically with either substrate in the presence of base and sediment.

\section{Shore-Based Microorganism Experiments: Cold Methane Production in Site 622 Sediment Slurries}

Cold methane production experiments were carried out with sediment slurries using the methods described in Oremland and Polcin (1982). Section 622-4-1 sediment was homogenized in a blender under nitrogen with an equal volume of artificial seawater. This seawater was composed of the following, in grams per liter: $\mathrm{NaCl}, 30$; magnesium chloride hexahydrate, 5.5 ; calcium carbonate dihydrate, 0.75 ; potassium chloride, 0.38; sodium bromide, 0.04; Wolin Trace Elements (Wolin et al., 1963), $10 \mathrm{ml}$; Wolin Vitamins, $7.5 \mathrm{ml}$; potassium phosphate dibasic, $\mathrm{K}_{2} \mathrm{HPO}_{4}, 0.25$; potassium phosphate monobasic, $\mathrm{KH}_{2} \mathrm{PO}_{4}$, 0.25 ; sodium bicarbonate, 0.25 ; and ammonium chloride, 1 . The slurry $(15 \mathrm{ml})$ was then transferred under nitrogen into a serum bottle containing $5 \mathrm{ml}$ of artificial seawater. Eight sets of triplicate flasks were prepared using the following compounds and conditions: no additives (nitrogen atmosphere); BES (2-bromoethane sulfonic acid, $140 \mathrm{mg}$ ); hydrogen atmosphere; autoclaved $\left(25 \mathrm{~min}\right.$. at $25 \mathrm{psi}$ and $\left.120^{\circ} \mathrm{C}\right)$; acetate $(27.2 \mathrm{mg}, 10 \mathrm{mM})$; methanol $(6.4 \mathrm{mg}, 10 \mathrm{mM})$; trimethylamine $(11.8 \mathrm{mg}, 10 \mathrm{mM})$; and dimethyl sulfide $(1.2 \mathrm{mg}, 1 \mathrm{mM})$. Methane production was followed by gas chromatography with flame ionization detectors over a period of about 2 months (Oremland and Polcin, 1982). Quantitation was via peak height using $1 \%$ methane external standard. Samples contained only traces of sorbed methane at the beginning of the experiments. Additional hydrogen (about $600 \mu M$ ) had to be added to the three "hydrogen" flasks over the course of the experiment because of development of negative gas pressure in the serum bottles containing this substrate.

\section{Interstitial Water Analyses}

Pore water was squeezed on board ship and frozen in the normal manner (Explanatory Notes, this volume). Aliquots for acetate analyses were stored in glass vials which had been previously ashed at $500^{\circ} \mathrm{C}$. Samples were treated with sodium hydroxide to adjust the $\mathrm{pH}$ to 10 and were then refrigerated. Pore water samples $(7 \mathrm{ml})$ for methylamine analyses were treated with $0.1 \mathrm{ml}$ of $6 \mathrm{~N}$ hydrochloric acid and frozen.

Acetate was measured by the gas chromatographic method of Christensen and Blackburn (1982) with the following modifications: Formic acid $(0.1 \%)$ was added as a diluent in preparation of standards, rather than to the carrier gas, to prevent peak tailing. On-column injection of samples was carried out using a Hewlett-Packard model 5790A GC equipped with a flame ionization detector and using nitrogen carrier gas. Quantitation was carried out by electronic integration of GC peaks. Without sample concentration, the lowest concentration of acetate detectable by this method is $9 \mu M$.

Amines were analyzed using modifications to the method of Lee and Olson (1984). The procedure involves a preliminary step of concentrating the sample followed by separation and detection of amines by gas chromatography. The pore waters were acidified to $\mathrm{pH} 2$ with $6 \mathrm{~N} \mathrm{HCl}$ and reduced to near dryness by rotary evaporation. The sample was then made basic to $\mathrm{pH}>11$ with $\mathrm{KOH}$ and vacuum distilled into dilute $\mathrm{HCl}$ using an apparatus similar to that of Christensen and Blackburn (1982). The resulting solution was reconcentrated by rotary evaporation, the residue taken up in $\mathrm{KOH}$, and a few microliters of the resulting basic solution injected onto a gas chromatograph equipped with a chemiluminescent nitrogen detector (Lee and Olson, 1984). GC analysis was carried out on a Chromosorb 102 column (Kuwata et al., 1983) via temperature programming from 100 to $170^{\circ} \mathrm{C}$ at $4^{\circ} \mathrm{C} / \mathrm{min}$. Peak areas were calculated by electronic integration. 


\section{RESULTS AND DISCUSSION}

\section{Shipboard Microorganism Experiments}

\section{Site 619}

Figure 2 shows results of incubations of aliquots of Site 619 sediments from various depths. All samples (with the exception of number 12 from $141 \mathrm{~m}$ which was not measured) produced ${ }^{35} \mathrm{SH}_{2}$ and ${ }^{14} \mathrm{CO}_{2}$, but no ${ }^{14} \mathrm{C}$-meth- ane was detected. We attempted to make a time series analysis by sacrificing individual samples at 3-day intervals. However, because of possible sample heterogeneity, it is not clear whether points can be viewed as a true time series rather than as individual aliquots. It does appear that two deep samples (from 113 and $167 \mathrm{~m}$ ) developed significant activity early in the experiment (within the time period of about 4-5 hr. between the times when cores were brought on deck and sampled and the time

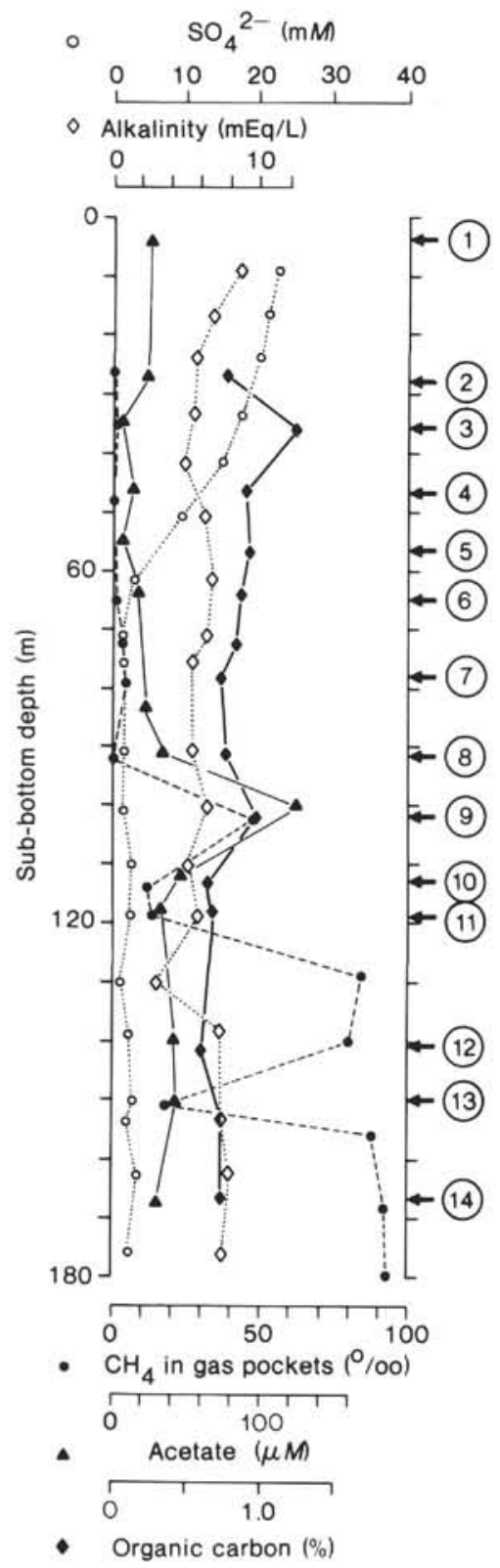

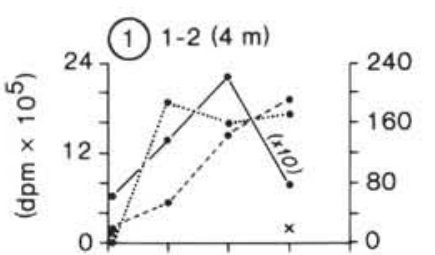
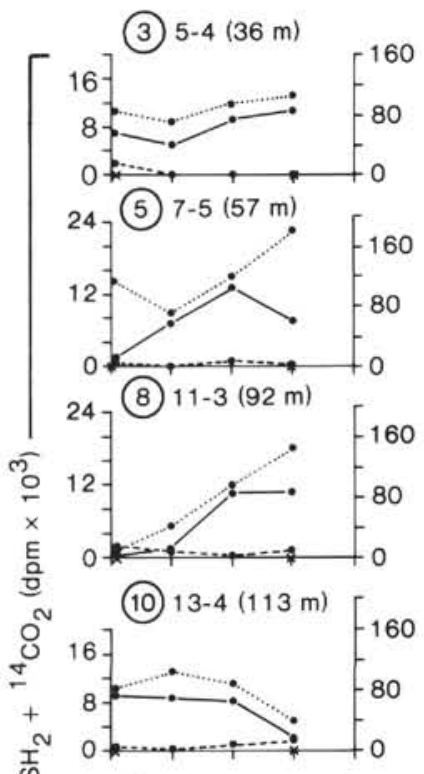

फ़

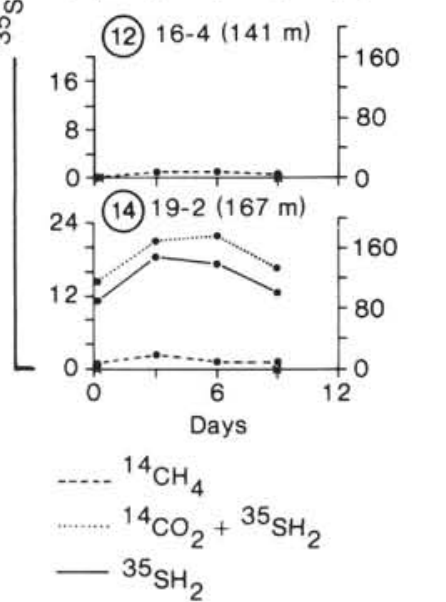

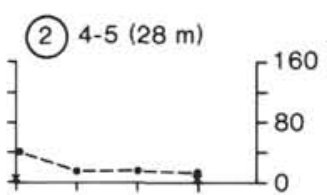

(4) $6-5(47 \mathrm{~m})$

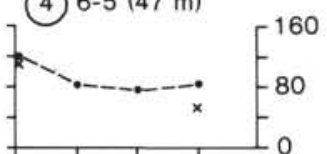

(6) $8-4(65 \mathrm{~m})$
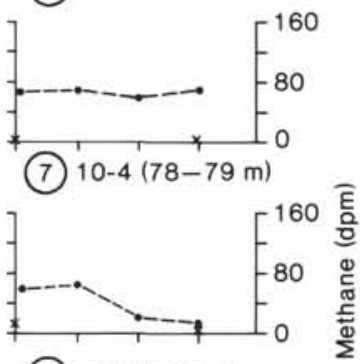

(9) $12-3(102 \mathrm{~m})$

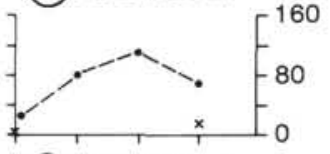

(11) $14-2(119 \mathrm{~m})$

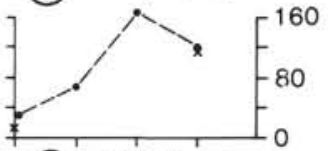

(13) $17-3(150 \mathrm{~m})$

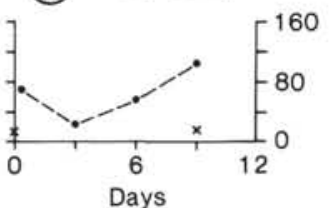

- Organic carbon $(\%)$

Figure 2. Summary of pore-water data and results from incubation of sediment with radiolabeled substrates: Site 619 (shipboard experiments). Circled numbers show depths from which samples were taken. The middle column shows results of experiments carried out with ${ }^{14} \mathrm{C}$-acetate and ${ }^{35} \mathrm{~S}$-sulfate. The right-hand column shows results of experiments using ${ }^{14} \mathrm{CH}_{4}$-methylamine. Levels of activity of ${ }^{35} \mathrm{SH}_{2}$ and ${ }^{14} \mathrm{CO}_{2}$ which developed as a function of time are shown as the solid and dotted lines respectively (scale on the left). Levels of activity of ${ }^{14} \mathrm{C}$-methane are also plotted (dashed line) on a scale which is 1000 times less than for the hydrogen sulfide and carbon dioxide (scale on the right). Background activity indicated by X's. 
the "zero" radiolabeling experiment could be prepared and stopped).

Results from ${ }^{14} \mathrm{C}$-labeled methylamine substrate are shown on the right-hand side of Figure 2. Significant methane ${ }^{14} \mathrm{C}$ activity above background (indicated by x's) was observed in some or all samples from $65,78,102$, 119 , and $150 \mathrm{~m}$. These activities are very low compared to either the production of ${ }^{14} \mathrm{CO}_{2}$ or ${ }^{35} \mathrm{SH}_{2}$ or to methane activity expected based on results from anoxic surface muds (about $10^{4}$ times less than those measured for San Francisco Bay surface sediment, described below and shown in Figs. 4 and 5) and would not have been measurable without utilizing the very sensitive scintillation counting technique. These low activities are not a chemical artifact. No production of ${ }^{14} \mathrm{C}$-methane occurred when ${ }^{14} \mathrm{C}$-trimethylamine or ${ }^{14} \mathrm{C}$-acetate was added to Site 622 sediment (very similar to that from Sites 618 and 619) and bacterial activity was arrested in the same way as the shipboard experiments (i.e., via injection of $2 \mathrm{ml}$ of $10 \mathrm{~N} \mathrm{NaOH}$ and then freezing).

\section{Site 618}

Results of radioisotope experiments for Site 618 are shown in Figure 3. In the acetate-sulfate experiments, high levels of ${ }^{14} \mathrm{CO}_{2}$ and ${ }^{35} \mathrm{SH}_{2}$ were observed for most time points at all depths. In the $40 \mathrm{~m}$ sample, ${ }^{14} \mathrm{C}$-methane production from acetate also had significant activity in two of the four samples.

In the ${ }^{14} \mathrm{C}$-methylamine experiments, significant activity was observed only for the $34 \mathrm{~m}$ sample. The ${ }^{14} \mathrm{C}$ methane in the 15 and $81 \mathrm{~m}$ samples remained near background levels.

\section{Site 622 and San Francisco Bay (shore-based laboratory experiments): Production of ${ }^{14} \mathrm{CH}_{4}$ from ${ }^{14} \mathrm{C}$-Acetate or ${ }^{14} \mathrm{C}$-Trimethylamine}

All of the experiments on Site 618 and 619 samples described above were carried out aboard ship. However, ${ }^{14} \mathrm{C}$-methane formation also occurred when similar sediment from Site 622 (Sample 622-4-1, 130-150 cm; 24 m sub-bottom) was sampled and incubated in a similar manner in the laboratory after 14 months of storage at $12^{\circ} \mathrm{C}$ in the sealed core liner. The ${ }^{14} \mathrm{C}$-methane production from $2-{ }^{14} \mathrm{C}$-acetate after 12 days of incubation was comparable to that produced in the shipboard experiments (compare the 5 and $40 \mathrm{~m}$ samples in Figs. 2 and 3, respectively with Fig. 4). Thus, long-term storage did not seem to destroy the organism responsible for producing the methane, although the period before activity became observable was longer than for the shipboard samples.

To check methodology and determine how a typical active nearshore anoxic mud would respond to our experimental conditions, surface mud from San Francisco Bay was also treated with ${ }^{14} \mathrm{C}$-acetate and ${ }^{14} \mathrm{C}$-trimethylamine under anoxic conditions. The results are shown in Figures 4 and 5. Development of activity was much more rapid and at least five orders of magnitude greater than observed in the deep-sea samples.

\section{Production of Methane by Sediment Slurries}

The sediment from Core 622-4 was slurried with water under nitrogen and then treated with artificial seawa- ter and various nutrients, as described above. BES (bromoethane sulfonic acid) was used in some of the flasks as a specific inhibitor for methanogenic bacteria (Oremland and Polcin, 1982). The flasks were monitored over a 2-month period for increases in gas phase (nonradiolabeled) methane. The flasks incubated under hydrogen gas were the only ones that showed a significant increase in methane over the course of the experiment (Fig. 6). (However, it should be kept in mind that small increases in methane, such as those shown in Figs. 2 and 3, would not have been measurable because GC is considerably less sensitive than the scintillation methane detection technique.) These flasks developed a negative gas pressure during the course of the incubation and were repressurized with about $600 \mu \mathrm{mol}$ hydrogen. Similar consumption of hydrogen by sediment microflora was observed in anoxic estuarine sediments (e.g., Oremland and Taylor, 1978). No significant increase in methane occurred in unamended controls or flasks supplemented with methanol, acetate, dimethylsulfide, or methylamine. In addition, methane levels in bromoethane sulfonic acid inhibited or autoclaved flasks were comparable to those in the unsupplemented controls $(\sim 4 \mathrm{nmol} /$ flask after 50 days). These results indicate that the increase of methane in the headspace of the unsupplemented control (Fig. 6) was due to desorption. However, enhanced methane production under hydrogen was caused by methanogenic bacterial activity.

\section{Geochemistry: Relationship to Possible In Situ Activity}

The experiments above suggest that low but significant bacterial activities occur in sediments recovered from a maximum of $167 \mathrm{~m}$ sub-bottom (age 85,000-110,000 yr.). The question then arises as to whether such activity might also be occurring (at a lower rate) in situ at depth. The geochemistry strongly suggests this as a possibility, as will be discussed more fully elsewhere. Briefly, it can be pointed out here that the substrates used in these experiments (sulfate, acetate, and methylamine) and the products which would be expected to be associated with microbiological activity $\left(\mathrm{H}_{2} \mathrm{~S}\right.$, alkalinity, $\mathrm{CO}_{2}$, and isotopically light methane), were also present in the sediment pore waters (Figs. 2 and 3 and Tables 1 and 2). However, the concentrations of substrates used in these shipboard and shore-based experiments are estimated to be considerably higher than those found in the natural system (Table 3).

In addition, deposition rates at all three sites are known to be generally very rapid-well in excess of the lower limit of $50 \mathrm{~m} / \mathrm{m} . \mathrm{y}$. postulated by Rice and Claypool (1981) to be necessary for methanogenic activity. Sediment organic carbon levels are also generally above the minimum value of $0.5 \%$ (Tables 1 and 2 ) which the same authors postulate are required by these organisms.

It should also be pointed out that the pore-water profile for Site 619 is almost identical in shape to that found for a surface core at Cape Lookout Bight (North Carolina) (Martens and Crill, 1984)-including the subsurface acetate maximum-except that the profile extends over centimeters in the Cape Lookout Bight case and tens of meters in the DSDP Leg 96 cases. Oremland et al. (1982) 

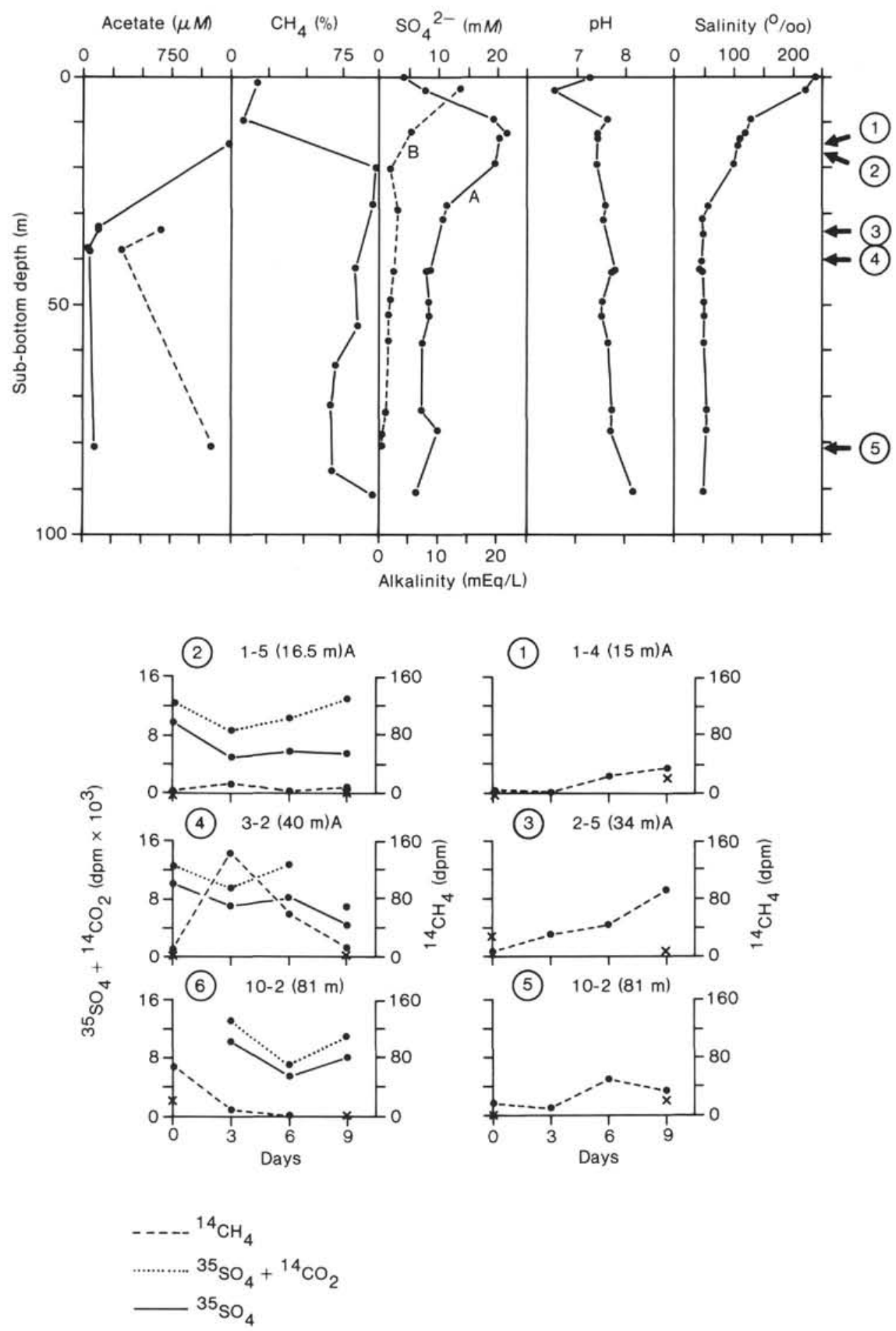

Figure 3. Summary of pore-water data and results from incubation of sediment with radiolabeled substrates: Site 618 (shipboard experiments). Bottom left column shows results of experiments using ${ }^{35} \mathrm{~S}$ sulfate and ${ }^{14} \mathrm{C}$-acetate; bottom right column shows results using ${ }^{14} \mathrm{C}$-methylamine. Dashed line in acetate profile shows $10 \times$ "blow up" of bottom part of profile. (A) alkalinity; (B) sulfate. Same abbreviations as in Figure 2.

have pointed out a similar situation for Leg 64 DSDP as compared to typical coastal sediment results.

We have no way of estimating from our data whether microbiological processes proceed at the same rate at depth (in situ) as in the shipboard and laboratory experiments, and these experiments were not designed to yield rate estimates. However, it is possible to speculate that if these organisms do operate at depth, the sediment organic carbon supply would be used up fairly quickly unless they operated at a slower rate at bottom pressures than at 1 atmosphere. Study of barotolerant surface sediment bacteria indicate that their metabolic 


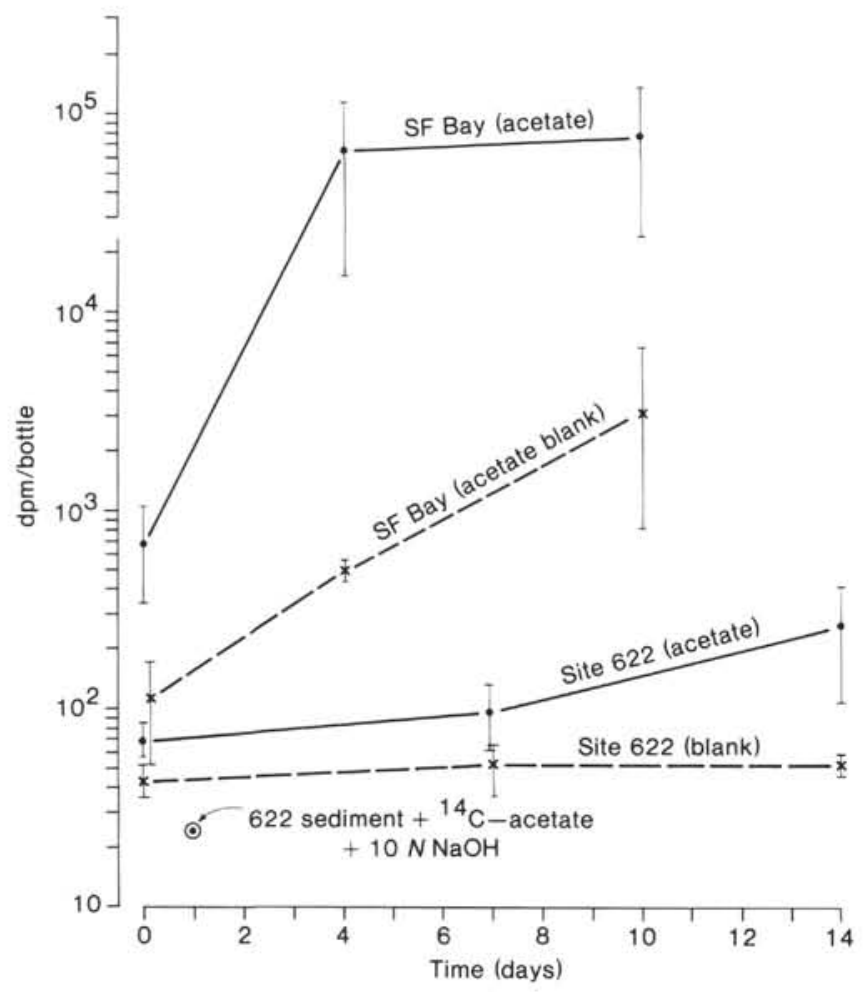

Figure 4. Incubation of sediments with ${ }^{14} \mathrm{C}$ acetate-shore-based experiments. Sediments are from San Francisco Bay (SF Bay acetate) and DSDP Site 622 in the Mississippi Fan (Site 622 acetate). Blanks indicate levels of residual radioactivity left in the ${ }^{14} \mathrm{C}$-methane gas line between analyses. " 622 sediment $+{ }^{14} \mathrm{C}$-acetate $+10 \mathrm{~N} \mathrm{NaOH}$ " indicates radioactivity produced by treatment of Site 622 sediment with radiolabeled substrate and sodium hydroxide.

rates often decrease at high pressures (Jannasch and Taylor, 1984). The magnitude of the effect varies from very slight to a reduction in rate of two orders of magnitude, depending primarily on the substrate involved. In addition, in situ bottom-water temperatures of $<10^{\circ} \mathrm{C}$, as compared to shipboard incubation temperatures of $15^{\circ} \mathrm{C}$, would also be expected to retard in situ activity. If anaerobes do survive in deep sediments, they might be well adapted to operating at very low metabolic rates so that the available nutrient supplies would last over geologic time.

\section{CONCLUSIONS}

Low levels of production of radiolabeled products were observed by incubating DSDP Site 618, 619, and 622 sediments from sub-bottom depths of 4 to $167 \mathrm{~m}$ with radiolabeled substrates. Types of microbiological activity observed include sulfate reduction from ${ }^{35} \mathrm{SO}_{4}$, carbon dioxide and methane production from $2-{ }^{14} \mathrm{C}$-labeled acetate, and ${ }^{14} \mathrm{C}$-methane production from ${ }^{14} \mathrm{C}$-labeled methylamine and trimethylamine. These substrates were also detected in pore waters and might also have been available to any viable organisms active at depth.

Comparison of shipboard and shore-based incubation results suggest that some microbiological activity was still present in one core (from Site 622) which had been stored at $5^{\circ} \mathrm{C}$ for 14 months.

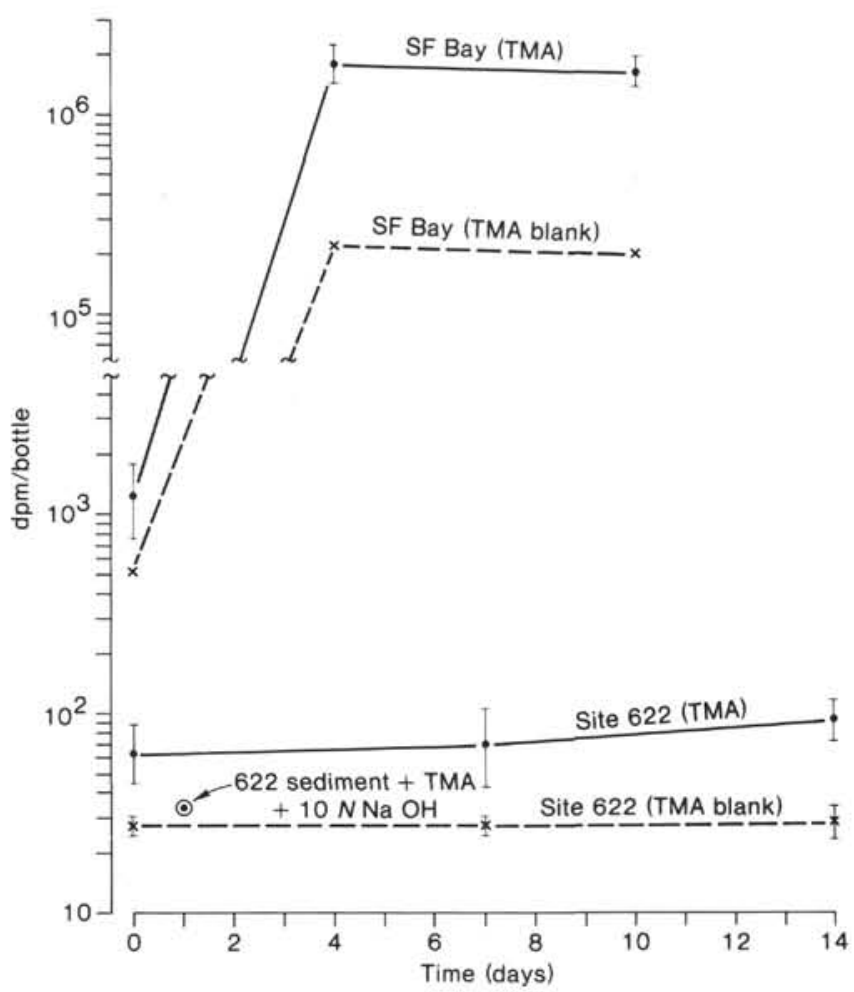

Figure 5. Incubation of sediments with ${ }^{14} \mathrm{C}$-trimethylamine-shorebased experiments. Labels same as for Figure 3, except that the substrate is ${ }^{14} \mathrm{C}$-trimethylamine rather than $2-{ }^{14} \mathrm{C}$-acetate.

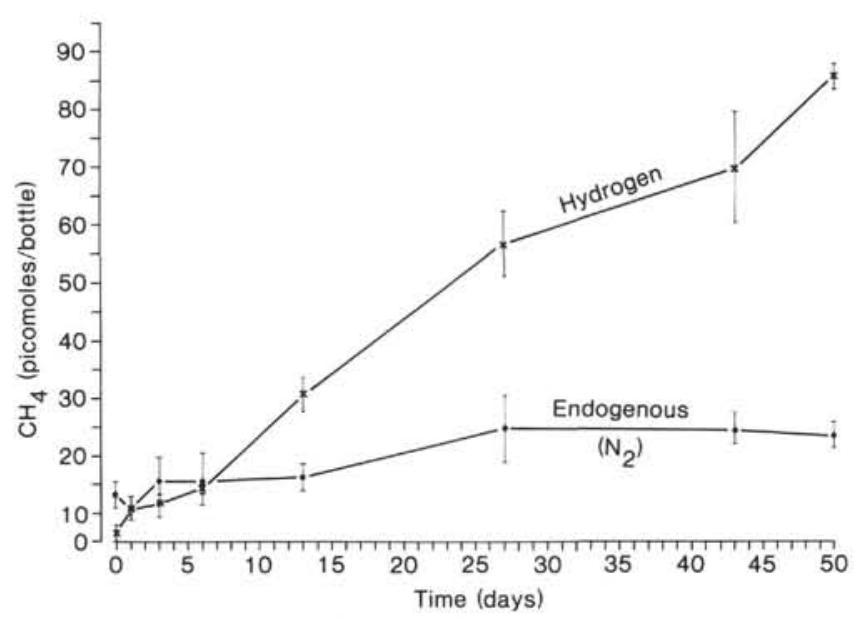

Figure 6. Methane production during incubation of slurries of Site 622 sediment under hydrogen or nitrogen (endogenous). Error bars represent $1 \sigma$ standard deviation on triplicate samples.

Methane formation by slurries from Site 622 sediment shows a significant increase only in the flasks maintained under hydrogen. These flasks also consumed hydrogen. No increase was observed when the sediment was maintained under nitrogen only or with methylamine, dimethylsulfide, methanol, or acetate substrates. These results indicate that $\mathrm{CO}_{2}$ reduction by hydrogen may be an important pathway for methane production in DSDP sediment. Future experiments should employ ${ }^{14} \mathrm{C}$-bicarbonate as a tracer for ${ }^{14} \mathrm{C}$-methane production. 
Table 1. Concentrations of interstitial water, methane, and other sediment components related to microorganisms at Site 619.

\begin{tabular}{|c|c|c|c|c|c|c|c|c|}
\hline \multirow[b]{2}{*}{ Core-Section ${ }^{\mathrm{a}}$} & \multirow{2}{*}{$\begin{array}{l}\text { Sub-bottom } \\
\text { depth (m) }\end{array}$} & \multirow{2}{*}{$\begin{array}{c}\text { Organic } \\
\text { carbon } \\
(\%)\end{array}$} & \multirow{2}{*}{$\begin{array}{c}\mathrm{CH}_{4} \text { in } \\
\text { core gas } \\
(\%)\end{array}$} & \multirow{2}{*}{$\begin{array}{c}\text { Acetate } \\
(\mu M)\end{array}$} & \multirow{2}{*}{$\begin{array}{l}\text { Sulfate } \\
(\mathrm{m} M)\end{array}$} & \multicolumn{3}{|c|}{$\begin{array}{l}\text { Methylamines ( } \mu M \text { ) } \\
\text { No. methyl groups }\end{array}$} \\
\hline & & & & & & Mono & Di & Tri \\
\hline $1-2$ & 4 & n.d. ${ }^{b}$ & 0 & $23 \pm 2.4$ & 29.9 & 0.7 & 0.1 & 0.04 \\
\hline $4-5$ & 28 & $0.78 \pm 0.006$ & $<1$ & $24 \pm 6.4$ & 17.8 & 0 & 0.08 & 0 \\
\hline $5-4$ & 36 & $1.13 \pm 0.001$ & 1 & 7 & 19.9 & 0.07 & 0 & 0 \\
\hline $6-5$ & 47 & $0.74 \pm 0.01$ & 0 & $14 \pm 0.08$ & 11.3 & 1.0 & 0 & 0 \\
\hline $7-5$ & 57 & 0.082 & 1 & $10.5 \pm 0.1$ & 6.8 & 0.10 & 0.07 & 0.02 \\
\hline $8-4$ & 65 & $0.82 \pm 0.03$ & 1.5 & $19.3 \pm 0.5$ & 0.5 & n.d. & n.d. & n.d. \\
\hline $9-3$ & & n.d. & 5 & n.d. & $1.04^{\mathrm{c}}$ & 0.20 & 0.20 & 0 \\
\hline $10-4$ & 78 & $0.74 \pm 0.02$ & $5^{\mathrm{d}}$ & $21 \pm 4.4$ & 0.4 & n.d. & n.d. & n.d. \\
\hline $11-3$ & 92 & $0.78 \pm 0.02$ & 0 & $38.5 \pm 0.4$ & 2.1 & n.d. & n.d. & n.d. \\
\hline $12-3$ & 102 & $0.09 \pm 0.002$ & 48 & $131 \pm 7.4$ & 2.9 & n.d. & n.d. & n.d. \\
\hline $13-4$ & 113 & $0.72 \pm 0.02$ & 12 & $49 \pm 0.01$ & 3.0 & 1.0 & 0 & 0 \\
\hline $14-2$ & 119 & $0.67 \pm 0.02$ & 13.5 & $31.5 \pm 5.3$ & 1.5 & n.d. & n.d. & n.d. \\
\hline $16-4$ & 141 & $0.56 \pm 0.001$ & 80 & $42 \pm 1.3$ & 2.6 & n.d. & n.d. & n.d. \\
\hline $17-3$ & 150 & $0.73 \pm 0.02$ & 18 & $43.8 \pm 2.5$ & 1.5 & 0.4 & 0.3 & 0 \\
\hline $19-2$ & 167 & $0.74 \pm 0.008$ & 92 & $52 \pm 19$ & 0.6 & n.d. & n.d. & n.d. \\
\hline
\end{tabular}

\footnotetext{
a All samples 130-150 cm, except for 14-2 (45-75 cm).

b n.d. = not determined.

c Determined for Sample 619-9-2, 135-150 cm by Ishizuka et al. (this volume).

d Pflaum et al. (this volume) report $40 \%$ for Section $619-10-2$.
}

Table 2. Concentrations of interstitial water, methanes, and other sediment components related to microorganisms at Site 618 .

\begin{tabular}{|c|c|c|c|c|c|c|c|c|c|}
\hline \multirow{2}{*}{$\begin{array}{c}\text { Sample } \\
\text { (interval in } \mathrm{cm} \text { ) }\end{array}$} & \multirow{2}{*}{$\begin{array}{l}\text { Sub-bottom } \\
\text { depth (m) }\end{array}$} & \multirow{2}{*}{$\begin{array}{c}\text { Organic } \\
\text { carbon } \\
(\%)\end{array}$} & \multirow{2}{*}{$\begin{array}{c}\mathrm{CH}_{4} \text { in } \\
\text { gas pockets } \\
(\%)\end{array}$} & \multirow[b]{2}{*}{$\delta^{13} \mathrm{C}^{\mathrm{a}}$} & \multirow{2}{*}{$\begin{array}{l}\text { Acetate } \\
(\mu M)\end{array}$} & \multirow{2}{*}{$\begin{array}{l}\text { Sulfate } \\
(\mathrm{m} M)\end{array}$} & \multicolumn{3}{|c|}{$\begin{array}{c}\text { Methylamines ( } \mu M) \\
\text { No. methyl groups }\end{array}$} \\
\hline & & & & & & & Mono & $\mathrm{Di}$ & Tri \\
\hline $1-4,130-150$ & 15 & $0.74 \pm 0.04$ & 5 & -74.9 & $>1225$ & 0.8 & 4.8 & 1.7 & 0 \\
\hline $2-5,0-40$ & 34.4 & $0.93 \pm 0.007$ & 85 & n.d. b & $58 \pm 12$ & 2.3 & n.d. & n.d. & n.d. \\
\hline $3-2,30-50$ & 39.5 & 0.71 & 80 & -73.3 & $35 \pm 1$ & 2.2 & 3.0 & 0.6 & 0 \\
\hline $10-2,70-90$ & 81.2 & n.d. & 70 & -73 to -76 & $108 \pm 3$ & 2.5 & 2.2 & 0.3 & 0.2 \\
\hline
\end{tabular}

a Data from Burke et al. (this volume).

b n.d. = not determined.

Table 3. Concentrations of radiolabeled substrates added to sediments compared with nonlabeled concentration occurring naturally in the same sections.

\begin{tabular}{lcc}
\hline \multicolumn{1}{c}{ Substrate } & Radiolabeled $^{\mathrm{a}}(\mu M)$ & Concentration in pore waters $^{\mathrm{b}}$ \\
\hline 14 C-methylamine & 54 & $4.8^{\mathrm{c}}$ \\
$1{ }^{14}$ C-acetate & 46 & $131 \mu M($ average $=36)$ \\
35 S-sulfate & 6.7 & $29.9 \mathrm{mM}$ \\
\hline
\end{tabular}

${ }^{\text {a }}$ Calculation assumes radiolabeled substrate distributed evenly throughout the sediment plug.

bighest concentration detected at Sites 618 and 619-see Tables 1 and 2.

${ }^{c}$ Highest concentration of trimethylamine detected was $0.2 \mu M$.

\section{ACKNOWLEDGMENTS}

C. Taylor reviewed an earlier version of this manuscript. We would like to thank Joan Brazier and Christine Burton for organic carbon, Brenda Olson for methylamine, and Elesia Mann for acetate measurements, and Margaret Harvey for typing the manuscript. We are particularly grateful to D. DesMarais and $\mathrm{N}$. Blair for advice on the ${ }^{14} \mathrm{CH}_{4}$ extraction system. This work is supported by NSF Grant OCE82-00485 (to Jean K. Whelan and John M. Hunt). Woods Hole Oceanographic Institution Contribution No. 6029.

\section{REFERENCES}

Belyaev, S. S., and Ivanov, M. V., 1983. Bacterial methanogenesis in underground waters. In Hallberg, R. (Ed.), Environmental Biogeochemistry. Ecol. Bull., 35:273-280.
Christensen, D., and Blackburn, T. H., 1982. Turnover of ${ }^{14} \mathrm{C}$-acetate in marine sediments. Mar. Biol., 71:113-119.

Claypool, G. E., and Kaplan, I. R., 1974. The origin and distribution of methane in marine sediments. In Kaplan, I. R. (Ed.), Natural Gases in Marine Sediments: New York (Plenum Press), pp. 99139.

Davis, J. B., 1967. Petroleum Microbiology: New York (Elsevier).

Jannasch, H. W., and Taylor, C. D., 1984. Deep-sea microbiology. Ann. Rev. Microbiol., 38:487-514.

Kuwata, K., Akiyama, E., Yamazaki, Y., Yamasaki, H., Kuge, Y., and Kiso, Y., 1983. Trace determination of low molecular weight aliphatic amines in air by gas chromatography. Anal. Chem., 55: 2199-2201.

Lee, C., and Olson, B. L., 1984. Dissolved, exchangeable and bound aliphatic amines in marine sediments: initial results. Org. Geochem., 6:259-263.

Martens, C. S., and Crill, P. M., 1984. Acetate cycling at the base of the sulfate reduction zone in an organic-rich coastal sediment. EOS Trans. Am. Geophys. Union, 65:905.

Oremland, R. S., Culbertson, C., and Simoneit, B. R. T., 1982. Methanogenic activity in sediment from Leg 64, Gulf of California. In Curray, J. R., Moore, D. G., et al., Init. Repts. DSDP, 64: Washington (U.S. Govt. Printing Office), 759-762.

Oremland, R. S., and Polcin, S., 1982. Methanogenesis and sulfate reduction: competitive and noncompetitive substrates in estuarine sediments. Appl. Environ. Micro., 44:1270-1276.

Oremland, R. S., and Taylor, B. F., 1978. Sulfate reduction and methanogenesis in marine sediments. Geochim. Cosomochim. Acta, 42:209-214.

Rice, D. D., and Claypool, G. E., 1981. Generation, accumulation and resource potential of biogenic gas. Am. Assoc. Pet. Geol. Bull., 65:5-25. 
Smith, R. L., and Klug, M. J., 1981a. Reduction of sulfur compounds in sediments of a eutrophic lake basin. Appl. Environ. Microbiol., 41:1230-1237.

1981b. Electron donors utilized by sulfate reducing bacterial in eutrophic lake sediments. Appl. Environ. Microbiol., 42: $116-121$.

Whelan, J. K., 1979. $C_{1}$ to $C_{7}$ hydrocarbons from IPOD Holes 397 and 397A. In von Rad, U., Ryan, W. B. F., et al., Init. Repts. DSDP, 47, Pt. 1: Washington (U.S. Govt. Printing Office), 531539.
Whelan, J. K., and Sato, S., 1980. $C_{1}-C_{5}$ hydrocarbons from core gas pockets, Deep Sea Drilling Project Legs 56 and 57, Japan Trench transect. In Scientific Party, Init. Repts. DSDP, 56, 57, Pt. 2: Washington (U.S. Govt. Printing Office), 1335-1347.

Wolin, E. A., Wolin, M. J., and Wolfe, R. S., 1963. Formation of methane by bacterial extracts. J. Biol. Chem., 121:184-191.

Date of Initial Receipt: 4 March 1985

Date of Acceptance: 6 September 1985 